\title{
Young Consumer's Perception on E-Service Quality of Online Shop: an Evidence from Bandung
}

\author{
Nina Septina \\ septina@unpar.ac.id \\ Universitas Katolik Parahyangan \\ Bandung, Indonesia
}

\begin{abstract}
Nowadays business runs not only by offline platform but also online. The online business growth facilitates by the rapid development of technology, especially internet. To enhance online consumer satisfaction, online businesses need to know the perceptions of consumers about the quality of its services as one of the basic considerations in decision making for their marketing policy. The limitation of this study was not discussed all platform of online business yet. This study applies mixed method to measure the perceptions of online consumers. Focus group discussion (FGD) conducted to learn the dimensions of e-service quality of young consumer in Bandung. Data collection was done through administered questionnaire which developed based on FGD findings and related literature. Eservice quality on this study consists of four dimensions which were reliability, tangibles, security and customer service. The results of this study found that respondents mostly satisfied on several dimensions of e-service quality and appreciate online shop as a partial substitute of offline shop. Moreover, male respondents less access than female but spends more.
\end{abstract}

Keywords- e-service quality, e-commerce, importance performance analysis, marketplace

\section{INTRODUCTION}

An increasing number of internet users in Indonesia, as by the end of 2013 were reach 71.19 million is an attractive opportunity for business to develop distribution channels through online marketing activities [1]. The use of mobile phones in the urbanized area of Indonesia has reached 88 percent and ownership of this communication device is one of the important factors that significantly affect the behavior of consumer spending. The results of the AC Nielsen survey conducted in 2014 found that Indonesia is in the top ranking globally in terms of the use of mobile phones for shopping online along with the Philippines, Thailand and Viet Nam; and all the countries in the Southeast Asia region produces a score above the global average [2].

One out of many factors influence in this changing is consumer perception. There is a need to understand perceived service quality of online shoppers as a strong evidence for strategist decision in online business. One way to measure the perception of the consumer is using dimensions of service quality. The situation of competition and the rapid advancement of technology encourage businessmen to pay more attention to the development of quality of service. Service quality is built on the existence of a comparison of two main components, namely consumer perception upon real service received (perceived service) and the expected service. With increasing use of internet technologies, service quality develops into an electronic-based to measure the perceptions of consumers' online using e-service quality.

Online shopping is a form of e-commerce which allows consumers to directly buy goods or services from a seller over the Internet. Online shop has alternative names such as e-shop, e-store, web-store, online store, and virtual store. Slow but sure, there is a changing of consumer behavior from offline to online platform. This changing is happening to all segments but more for the younger one. The millennial (age 21-34 years old) are age segment which has grown up in the digital era. They are highly contact with the internet on daily basis and experience more from the online platform. In this context, there is a need to identify and understand perceived e-service quality online of the millennial.

Since the internet is a relatively new transactional channel, online shop possibly not clearly understand what specific services are desired. Moreover, many customers have not yet formed clear expectations for online retailers [3].

The importance of service quality and the challenges facing an internet-based services necessitate insights on the part of online shop owner or/and manager about what attributes customers use in their evaluation of e-service quality. However, a rigorous measurement instrument of online service quality has not been available [4].

Base on the above explanation, the research question is as follow:

- What dimension of service quality should be consisted of in online shop context?

- How online shop perceived by young consumer at Bandung?

This research aims to study the dimensions of e-service quality appropriate to measure the perceptions of consumers online in Bandung city so their perception towards e-service quality online shopping sites can be described clearly.

\section{DimENSION OF E-SERVICE QUALITY}

In the emerging service industry, it is important to measure the service quality. Customer perceived service quality defined as a global judgment or attitude relating to the superiority of a service relative to competing offerings [5]. The importance of service quality is already well known [e.g. 6, 7, 8]. 
Over the past three decades, numerous studies have sought to uncover the global services attributes that contribute most significantly to more relevant quality assessments [e.g. 7, 9]. Among them, work of the Parasuraman et al. [7] has been regarded as most prominent, which revealed ten dimensions. These ten dimensions were further purified and distilled to five as tangibles, reliability, responsibility, assurance and empathy [5]. In turn, these five attributes constitute the base of a global measurement devise for service quality, namely, SERVQUAL which has been applied by various researchers to numerous service industries as a means of gauging service quality.

Since SERVQUAL was not valid for every industry, it was suggested that the validity of SERVQUAL should be examined in a variety of service industries and the adaptations of items in SERVQUAL for each industry should be organized [e.g. 10, 11, 12 and 13].

Apparently SERVQUAL may not be sufficient for measuring service quality across industries and situations include online service quality. It does not consider unique facets of online service quality, since the five dimensions primarily address customer to employee, but not customer to website interactions. Accordingly, some studies have attempted to identify key attributes that best fit the online business environment.

The study of Zeithaml et al. [3] uncovered 11 dimensions of online service quality in a series of focus group interviews. These were access, ease of navigation, efficiency, flexibility, reliability, personalization, security, responsiveness, assurance/trust, site aesthetics, and price knowledge. Yoo and Donthu [14] developed a psychometrically measure of service quality of online shopping websites and developed SITEQUAL, consist of ease of use, aesthetic, processing speed, and security.

Barnes and Vidgen [15] established a WebQual Index with 24 measurement items. The index addresses the following seven customer service quality aspects: reliability, competence, responsiveness, access, credibility, communication, and understanding the individual. Similarly, Madu and Madu [16] have proposed the following 15 dimensions of online service quality as performance, features, structure, aesthetics; (5) reliability, storage capacity, serviceability, security and system integrity, trust, responsiveness, product differentiation and customization, web store policies, reputation, assurance and empathy.

Wolfinbarger and Gilly [17] have uncovered four factors of online retailing experience; eTailQ as web site design, reliability, security, and customer service, in line with Field et al [18].

Further, Zeithaml et al. [19] have discovered the following seven service quality dimensions as efficiency, reliability, fulfillment, privacy, responsiveness, compensation, and contact. Another scale, e-tailers, was developed as PIRQUAL; Perceived Internet Retail Quality Model by Francis and White [20], consists of six dimensions such as web store functionality, product attribute description, ownership conditions, delivery, customer service, and security. Santos [21] proposed e-service quality dimensions that can be classified in two ways as incubate dimensions (ease of use, appearance, linkage, structure and layout, and content) and active dimensions (reliability, efficiency, support, communication, security, and incentive).

Parasuraman et al. [22] proposed E-S-QUAL and E-RecSQUAL scales for measuring e-service quality. E-S-QUAL (efficiency, fulfillment, system availability, and privacy) was a core service quality scale for measuring core service attributes of websites and E-RecS-Qual (responsiveness, compensation, and contact) was an e-recovery service quality scale which measures the quality of recovery services provided by websites. E-S-QUAL was adapted to different industries for example on online shopping; e.g. Rafiq et al., 2012 [23]; Ingle and Connoly, 2006 [24]; Meng and Mummalaneni, 2010 [25], internet banking; e.g. Wu et al., 2012 [26]; Kayabasi et al., 2013 [27], and mobile service quality; e.g. Ozer et al., 2013 [28]).

\section{Methodology}

Mixed method employed to this study. As an initial phase of this study, focus group of discussion involved different representative's groups conducted, as done by Parasuraman et al. [29], to identify a series of appropriate attributes of eservice quality dimension. The next phase was quantified the dimensions found in focus group discussion and compared to dimensions found on similar previous study. The instrument of survey derived from these two sources. An administered questionnaire tried out to finalize wording in measure each indicator of dimensions of service quality in the context of online shop.

This study limits to measure perceived service quality of young consumer (the millennial) on business to consumer (i.e., Lazada, Matahari Mall, BliBli, Traveloka) consumer to consumer (i.e OLX, Kaskus) online shopping. Population of young citizen (age between 20 and 34 years old) at Bandung in the years of 2014 is 711,458 out of $2,470,802$ people [30].

Respondents should meet the criteria as young citizen at Bandung who had online shopping experience recently, at least within last month. Young internet information searcher did not meet this criterion. The respondents were asked to evaluate the online shop on several indicators of service quality dimensions on a five point Likert-type scale. The scale was anchored by "strongly disagree" and "strongly agree". They were also evaluated the importance of each indicator on a similar a five rating scale, anchored by "not important at all" and "very important".

Data collection process conducted for about five months, from January until February 2016 for Focus Group Discussion; continued by instrument development, questionnaire distribution, and data analysis using SPSS between March and May 2016.

According the Importance Performance Analysis (IPA); formulated by Martilla and James [31], respondent's rating plotted on Cartesian Diagram to grouping each attributes and dimension on appropriate quadrant criterion. 


\section{RESUlT AND DisCUSSION}

Three sessions of focus group discussion with totally 26 participants were transcribed. After coded and categorized, it result several indicators for each dimension of e-service quality. The dimensions in this study were reliability, tangibles, security and customer service not only similar to Field et al [18] but also Wolfinbarger and Gilly [17] which were website design, reliability, security, and customer service.

TABLE I. PROFILE OF RESPONDENTS

\begin{tabular}{|c|c|c|c|c|}
\hline \multirow[t]{2}{*}{ Sex } & \multicolumn{4}{|c|}{ Age (years old) } \\
\hline & $<24$ & -29 & $>30$ & Total \\
\hline Male & 24 & 88 & 20 & 148 \\
\hline Female & 52 & 83 & 28 & 163 \\
\hline Total & 92 & 171 & 48 & 311 \\
\hline
\end{tabular}

Survey with totally 311 young online shoppers at Bandung responded to administered questionnaire. Descriptive analysis revealed that 47.59 per cent of respondents were male and 52.41 per cent were female. Respondents less than 24 years old, between 25 and 29 years old, and more than 30 years old were respectively 29.58 per cent, 54.98 per cent and 15.43 percent (Table 1). In average, male respondents access online shop 2.5 hours a day and spend IDR 450,000 per transaction while female respondents access 4.5 hours and spend IDR 120,000. All respondent appreciates online shop as a partial substitute of offline shop.

Internal consistency measured with Cronbach's alpha, a statistic calculated from the pairwise correlations between items. Internal consistency describes the extent to which all the items in a test measure the same concept or construct and hence it is connected to the inter-relatedness of the items within the test. Consider Nunnally and Bernstein [32] the results of the reliability analysis show that the coefficient alphas were above 0.80 for all the attributes, thereby lending support to the suitability of the items in each dimension.

Quadrant analysis mapping consumer responses to attributes that were plotted based on rating of importance (expectation) and performance of each attribute. There are four quadrants as quadrant 1 labeled as 'concentrate here', quadrant 2 as 'keep up the good work', quadrant 3 as 'low priority', and quadrant 4 as 'possible overkill'.

Table II and Figure 1 describe that on quadrant 1 plotted attributes $5,10,12,14,15,18$ and 23 . While on quadrant 2 there were attributes $2,8,9,11,13,20,22$ and total tangible dimension (26). Moreover, on quadrant 3 there were attributes $1,3,4,16,17,21$, and total dimension of reliability (25) and security (27). And, on quadrant 4 there were attributes 6, 7, 19, 24 and total dimension of customer service (28).
TABLE II. PERCEPTUAl MEANS OF RESPONDENTS

\begin{tabular}{|c|c|c|c|c|}
\hline \multirow[b]{2}{*}{$\begin{array}{l}\text { Attributes and } \\
\text { Dimensions }\end{array}$} & \multirow[b]{2}{*}{ Label } & \multirow[b]{2}{*}{ Quadrant } & \multicolumn{2}{|c|}{ Mean of Respondent's Rating } \\
\hline & & & $\begin{array}{c}\text { Importance } \\
\text { (Expectation) }\end{array}$ & Performance \\
\hline \multicolumn{5}{|l|}{ Reliability } \\
\hline TR1 & $(1)$ & 3 & 4.44 & 3.54 \\
\hline TR2 & (2) & 2 & 4.54 & 3.59 \\
\hline TR3 & (3) & 3 & 4.50 & 3.53 \\
\hline TR4 & (4) & 3 & 4.51 & 3.48 \\
\hline TR5 & (5) & 1 & 4.61 & 3.68 \\
\hline TR6 & (7) & 4 & 4.57 & 3.57 \\
\hline \multicolumn{5}{|l|}{ Tangible } \\
\hline TT1 & $(6)$ & 4 & 4.50 & 3.50 \\
\hline TT2 & $(8)$ & 2 & 4.55 & 3.40 \\
\hline TT3 & (9) & 2 & 4.54 & 3.61 \\
\hline TT4 & $(10)$ & 1 & 4.56 & 3.64 \\
\hline TT5 & (11) & 2 & 4.52 & 3.51 \\
\hline TT6 & (12) & 1 & 4.59 & 3.50 \\
\hline TT7 & (13) & 2 & 4.63 & 3.43 \\
\hline TT8 & (16) & 3 & 4.59 & 3.68 \\
\hline TT9 & (17) & 3 & 4.60 & 3.54 \\
\hline \multicolumn{5}{|l|}{ Security } \\
\hline TS1 & (14) & 1 & 4.50 & 3.59 \\
\hline TS2 & (15) & 1 & 4.58 & 3.68 \\
\hline TS3 & (18) & 1 & 4.50 & 3.67 \\
\hline TS4 & (19) & 4 & 4.61 & 3.50 \\
\hline \multicolumn{5}{|l|}{$\begin{array}{l}\text { Customer } \\
\text { Service }\end{array}$} \\
\hline TC1 & $(20)$ & 2 & 4.52 & 3.60 \\
\hline TC2 & $(21)$ & 3 & 4.55 & 3.52 \\
\hline TC3 & $(22)$ & 2 & 4.53 & 3.54 \\
\hline TC4 & (23) & 1 & 4.50 & 3.43 \\
\hline TC5 & (24) & 4 & 4.59 & 3.50 \\
\hline Reliability & (25) & 3 & 4.53 & 3.56 \\
\hline Tangible & (26) & 2 & 4.56 & 3.53 \\
\hline Security & (27) & 3 & 4.55 & 3.61 \\
\hline CustomerService & (28) & 4 & 4.54 & 3.52 \\
\hline
\end{tabular}

The performance of attributes or dimension on quadrant 1 was lower than respondent's expectation. This performance leads to customer dissatisfaction. Online shop should increase their performance on attribute plotted on this quadrant. The respondents were high demand on expecting to receive perfectly the same product with the picture on the website, complete production information, picture on the web captured from different angles, facilitating by escrow for payment, offer cash on delivery as alternative choice of payment, personal 
data highly secure, and quick respond on respondent's question. Online shop need to improve their performance on these attributes as they did not meet the respondents' expectation yet.

The performance and expectation were on high level and appropriate on quadrant 2. Attributes and dimension of service quality on this quadrant were met the expectation respondents which leads to sufficient satisfaction. Respondents satisfied for product received met their order, user friendly web navigation, clear product information, good resolution and real picture on the web, contact person ease to reach, and answer respondent's question politely. Online shop should maintain these attributes carefully.

On quadrant 3 performance and expectation were at a low level. This mean online shop has not need to make significant improvements immediately on ready stock information, delivery time, personalization communication, grouping product, and friendly respond on respondent's question. As these attributes expected at low level, online shop do not need too much effort to improve their performance; better to allocate more effort on other attributes on quadrant 1.

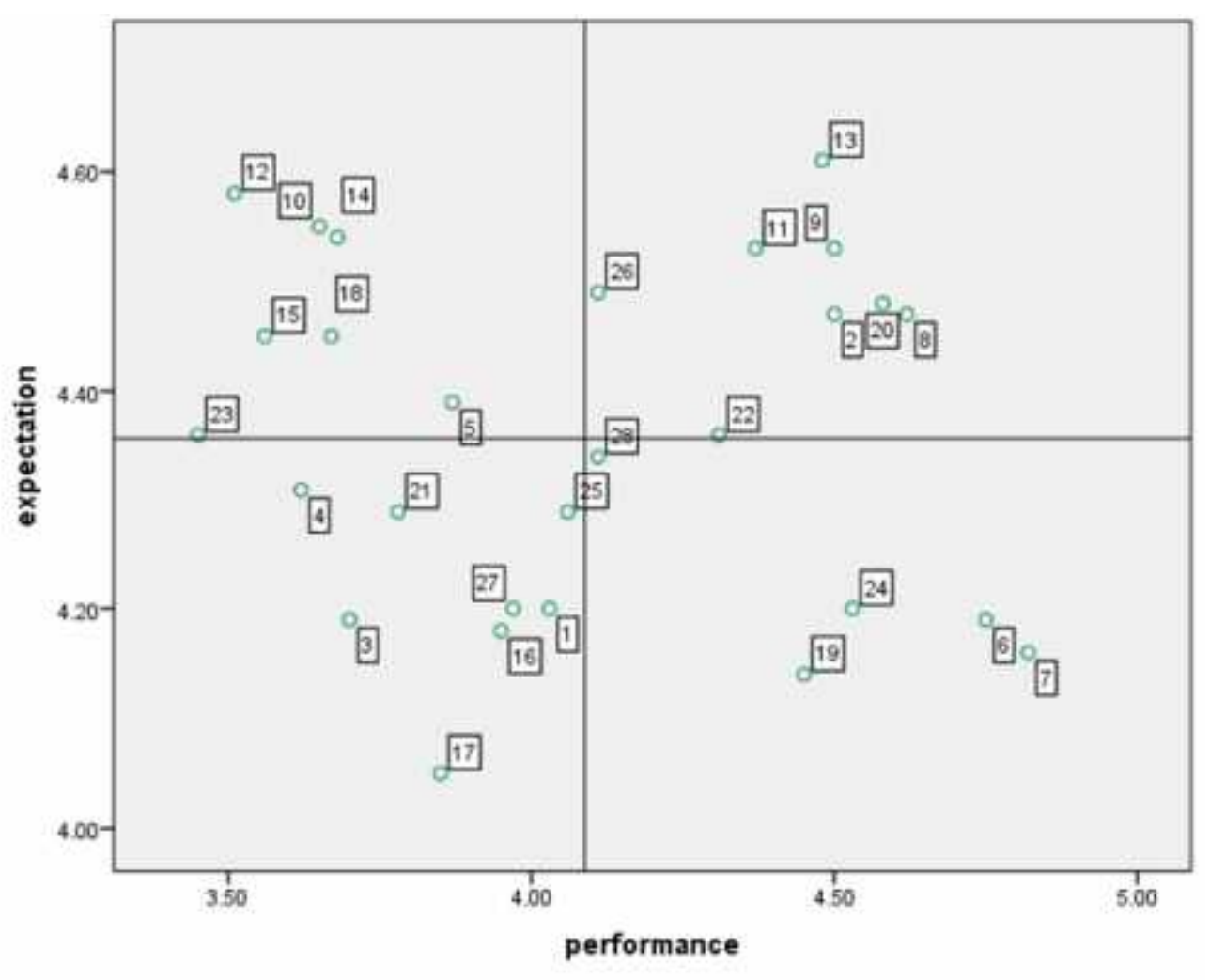

Fig. 1. Importance Performance Cartesian Diagram

On quadrant 4 performance of online shop was at high level while respondent expectation was low. Online shop need to reduce the effort on the attributes and dimensions plotted on this quadrant to minimize resources allocated. They should decrease attention on delivery packaging design, good design website, testimony list, and offer best solution for respondent's problem.

Respondents perceived dimension of tangible plotted on quadrant 2. It means that these dimension rated as well perform. Online shop should keep up their strategic effort on tangible dimension. Reliability and security were plotted on the quadrant 3, means these dimensions rated as low priority. There is not urgent for online shop to pay more attention on these. While customer service perceived as dimension on quadrant 4. It means online shop had done too much effort on this dimension. They should decrease their level of customer service dimension.

\section{FUTURE RESEARCH}

Future study possibly to address in the same context for more samples in several urban areas in Indonesia, comparing to other age of category, concerning offline and online survey, and covering all internet user.

\section{REFERENCES}

[1] Marius P. and Pinontoan, F., Indonesia Internet Usage for Business Sector, 2013, Indonesian Internet Service Provider Association and Central Bureau of Statistics, Jakarta.

[2] Nielsen Global Survey of E-Commerce, Q1 2014, www.nielsen.com.

[3] Zeithaml, V.A., Parasuraman, A. and Malhotra, A. (2001), "A conceptual framework for understanding e-service quality: implications for future research and managerial practice", MSI Working Paper Series, Report Number 00-115, Cambridge, MA.

[4] Cox, J. and Dale, B.G. (2001), "Service quality and e-commerce: an exploratory analysis", Managing Service Quality, 11 (2), 121-31. 
[5] Parasuraman, A., Zeithaml, V.A. and Berry, L.L. (1988), "SERVQUAL: a multiple-item scale for measuring consumer perceptions of service quality”, Journal of Retailing, 64 (1), 12-40.

[6] Grönroos, C. (1984). A service quality model and its marketing implications. European Journal of Marketing, 18(4), 36-44.

[7] Parasuraman, A., Zeithaml, V.A. and Berry, L.L. (1985), "A conceptual model of service quality and its implications for future research", Journal of Marketing, Vol. 49 (4), 41-50.

[8] Mangold, W. G., and Babakus, E. (1990). Monitoring service quality. Review of Business, 11(4), 21-27.

[9] Sasser, W.E. Jr, Olsen, R.P. and Wyckoff, D.D. (1978), Management of Service Operations: Text and Cases, Allyn \& Bacon, Boston, MA.

[10] Finn, D. W. and Lamb Jr, C. W. (1991). An evaluation of the SERVQUAL Scales in a retailing setting. Advances in Consumer Research, 18(1), 483-490.

[11] Babakus, E. and Boller, G. W. (1992). An empirical assessment of the SERVQUAL scale. Journal of Business Research, 24(3), 253-268.

[12] Brown, T. J., Churchill Jr, G. A. and Peter, J. P. (1993). Improving the measurement of service quality. Journal of Retailing, 69(1), 127-139.

[13] Ryan, C., and A. Cliff (1996). Users and non-users on the expectation item of the SERVQUAL scale. Annals of Tourism Research, 23(4), 931934.

[14] Yoo, B. and Donthu, N. (2001). Developing a scale to measure the perceived quality of an Internet shopping site (SITEQUAL). Quarterly Journal of Electronic Commerce, 2(1), 31-45.

[15] Barnes, S.J. and Vidgen, R. (2001), “An evaluation of cyber-bookshops: the WebQual method", International Journal of Electronic Commerce, 6 (1), 11-30.

[16] Madu, C.N., and Madu, A.A. (2002), "Dimensions of e-quality", International Journal of Quality and Reliability Management, 19 (3), 246-58.

[17] Wolfinbarger, M.F. and Gilly, M.C. (2003), "eTailQ: dimensionalizing, measuring and predicting etail quality", Journal of Retailing, 79 (3), 183-98.

[18] Field, J.M., Heim, G.R. and Sinha, K.K. (2004). Managing quality in the eservice system: Development and application of a process model. Production and Operations Management, 13(4), 291-306.

[19] Zeithaml, V.A., Parasuraman, A. and Malhotra, A. (2002), "Service quality delivery through Web sites: a critical review of extant knowledge", Journal of the Academy of Marketing Science, 30 (4), 36275 .
[20] Francis, J. E. and White, L. (2002). PIRQUAL: a scale for measuring customer expectations and perceptions of quality in internet retailing. In Proceedings of the 2002 American Marketing Association Winter Educators' Conference: marketing theory and applications, 13, 263-70.

[21] Santos, J. (2003). E-service quality: a model of virtual service quality dimensions. Managing Service Quality, 13(3), 233-246.

[22] Parasuraman, A., Zeithaml, V. A. and Malhotra, A. (2005). ES-QUAL a multiple- item scale for assessing electronic service quality. Journal of Service Research, 7(3), 213-233.

[23] Rafiq, M., Lu, X. and Fulford, H. (2012).Measuring Internet retail service quality using E-S-QUAL. Journal of Marketing Management, 28(9-10), 1159-1173.

[24] Ingle, S. and Connolly, R. (2006). Methodological and research issues using ES-QUAL to measure online service quality in Irish SMEs. Irish Journal of Management, 27(2)., 25-32.

[25] Meng, J. and Mummalaneni, V. (2010). Measurement equivalency of web service quality instruments: A test on Chinese and African American consumers. Journal of International Consumer Marketing, 22(3), 259-269.

[26] Wu, Y. L., Tao, Y. H., and Yang, P. C. (2012). Learning from the past and present: measuring Internet banking service quality. The Service Industries Journal, 32(3), 477-497.

[27] Kayabasi, A., Celik, B., and Buyukarslan, A. (2013). The analysis of the relationship among perceived electronic service quality, total service quality and total satisfaction in banking sector. International Journal of Human Sciences, 10(2), 304-325.

[28] Ozer, A., Argan, M. T. and Argan, M. (2013). The effect of mobile service quality dimensions on customer satisfaction. Procedia-Social and Behavioral Sciences, 99, 428-438.

[29] Parasuraman, A., Zeithaml, Valerie A., and Berry, Leonard L. (1991) "Refinement and reassessment of theSERVQUAL scale, Journal of Retailing, 67(4), 420-50

[30] Bandung City in Figures, 2015, Statistics of Bandung City, Bandung.

[31] Martilla, J., and James, J. (1977). "Importance-Performance Analysis." Journal Of Marketing, 41 (1):77-79.

[32] Nunnally, J.C. and Bernstein, I.H. (1994), Psychometric Theory, McGraw-Hall, New York, NY. Oliva, T.A., Oliver, R.L. and MacMillan, I.C. (1992), "A catastrophe model for developing service satisfaction strategies", Journal of Marketing, 56 (3), 83-95. 